J. Dairy Sci. 92:526-539

doi:10.3168/jds.2008-1421

(C) American Dairy Science Association, 2009.

\title{
Somatotropic axis components and nutrient partitioning in genetically diverse dairy cows managed under different feed allowances in a pasture system
}

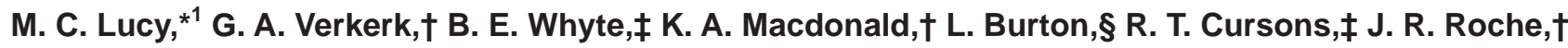 \\ and C. W. Holmes\# \\ *Department of Animal Sciences, University of Missouri, Columbia 65211 \\ †DairyNZ Ltd., Hamilton, New Zealand \\ fUniversity of Waikato, Hamilton, New Zealand \\ §Fonterra, Auckland, New Zealand \\ \#Massey University, Palmerston North, New Zealand
}

\begin{abstract}
The somatotropic axis [including growth hormone (GH), GH receptor, and insulin-like growth factor (IGF)-I] is uncoupled in high-producing cows in early lactation so that the liver fails to respond to $\mathrm{GH}$ and produces less IGF-I. This uncoupling was implicated in the process of nutrient partitioning, enabling high milk production. Different genetic selection goals may affect functional components of the somatotropic axis. Thus, the somatotropic axis was examined in diverse genetic strains of dairy cows [North American Holstein 1990 (NA90), New Zealand Holstein-Friesian 1990 (NZ90), and New Zealand Holstein-Friesian 1970 (NZ70)] that were managed similarly within a pasture-based system but were offered feed allowances commensurate with their genetic ability to produce milk. The NA90 cows produced more milk $(26.2 \pm 0.3,24.1 \pm 0.3$, and 20.1 $\pm 0.4 \mathrm{~kg} / \mathrm{d}$, for NA90, NZ90, and NZ70, respectively), but had lower milk fat percentages $(4.28 \pm 0.03,4.69 \pm$ 0.03 , and $4.58 \pm 0.04 \mathrm{~kg} / \mathrm{d}$ for NA90, NZ90, and NZ70, respectively) compared with both NZ strains. Milk protein percentages $(3.38 \pm 0.02,3.52 \pm 0.02$, and 3.29 $\pm 0.03 \mathrm{~kg} / \mathrm{d}$ for NA90, NZ90, and NZ70, respectively) were greater for NZ90 cows. During early lactation (wk 2 to 6 ), the total net energy produced in milk was greater in NA90 compared with NZ90 or NZ70 cows, but total net energy in milk after wk 6 was equivalent for NA90 and NZ90 cows. The greater milk production in early lactation in NA90 cows was associated with lower body condition scores (BCS; 1 to 10 scale; $4.0 \pm 0.1$ ) elevated blood GH concentrations (1.6 \pm $0.1 \mathrm{ng} / \mathrm{mL}$ ), and low blood IGF-I concentrations (14.8 $\pm 1.1 \mathrm{ng} / \mathrm{mL}$ ), indicating an uncoupled somatotropic axis. In comparison, the NZ70 cows retained a coupled
\end{abstract}

Received June 3, 2008.

Accepted September 16, 2008.

${ }^{1}$ Corresponding author: lucym@missouri.edu somatotropic axis during early lactation, maintaining greater BCS $(4.6 \pm 0.1)$, lower blood GH $(0.7 \pm 0.1 \mathrm{ng} /$ $\mathrm{mL})$, and greater blood IGF-I $(21.9 \pm 1.2 \mathrm{ng} / \mathrm{mL})$. The degree of uncoupling in NZ90 cows was intermediate between the other 2 strains. Additional feed allowance failed to change blood IGF-I concentrations in NA90 cows but increased IGF-I concentrations in NZ90 cows $(20.9 \pm 1.4$ and $13.2 \pm 1.4 \mathrm{ng} / \mathrm{mL}$ for the high and low feed allowance, respectively). Furthermore, additional feed allowance in NZ90 cows lessened BCS loss in early lactation, but did not affect BCS loss in NA90 cows. Functional components of the somatotropic axis differed for the respective strains and were consistent with strain differences in milk production, BCS, and feed allowance.

Key words: somatotropic axis, genetic selection, nutrient partitioning

\section{INTRODUCTION}

Genetic selection is generally applied to dairy cattle for the purpose of improving profitability, and dairy selection indices in the United States before mid-1990 were weighted heavily for milk production (Shook, 2006). In comparison, selection in seasonal calving systems included nonproduction traits relating to the profitability of the system and the longevity of the cow within the system (Harris and Kolver, 2001). Focused selection for milk production caused a rapid increase in milk production per cow. In addition to greater milk production, genetically selected dairy cows had lower BCS (Hansen, 2000). The lower BCS was explained by the process of nutrient partitioning during early lactation, which supported a rapid ascent to peak milk production (Drackley et al., 2006) and the failure of these cows to partition nutrients to BCS replenishment (Roche et al., 2006). This increased nutrient partitioning to milk production was associated with low reproductive performance (Chagas et al., 2007; Roche et al., 
2007). Continuously calving herds [commonly found in North America (NA)] tolerate reproductive inefficiency because a yearly calving interval is not required and a prolonged breeding period is feasible (Lucy, 2007). In seasonal-calving herds [commonly found in Australia, New Zealand (NZ), and some parts of Western Europe], reduced reproductive performance represents a serious problem, because cows that fail to conceive during the breeding period (approximately 40 to $100 \mathrm{~d}$ postpartum) are culled (Harris, 2005).

The somatotropic axis, consisting of growth hormone (GH), the GH receptor (GHR), IGF-I, and IGF-binding proteins (IGFBP), controls nutrient partitioning in early-lactation dairy cows (Etherton and Bauman, 1998; Lucy et al., 2001; Etherton, 2004). There was a rapid decrease in liver GHR mRNA expression and blood IGF-I concentration shortly after calving (Radcliff et al., 2003a,b; Lucy, 2008). The decrease in blood IGF-I (the primary negative feedback loop for GH) is associated with increased blood GH concentrations. The increase in blood GH drives nutrient partitioning during early lactation. The aforementioned studies of the somatotropic axis were done in NA dairy cows, for which nutrient partitioning to milk production was viewed as desirable in early lactation (Hansen, 2000). In seasonal-calving herds, excessive nutrient partitioning to milk production is considered less desirable because of potential negative effects on reproductive performance (Harris, 2005; Roche et al., 2007). Furthermore, nutrient partitioning to milk production was less in NZ cows compared with NA cows (Roche et al., 2006). We hypothesized that genetic selection for traits other than milk production constrained the changes in the somatotropic axis that were observed in NA studies. Furthermore, lower producing dairy cows will not undergo as severe a BCS loss or the coordinated changes in GH and IGF-I evident in high-producing dairy cows in early postpartum. To test this hypothesis, production traits and the somatotropic axis were studied in NA Holstein cows having genetics typical of the mid-1990s (NA90; high milk production), NZ Holstein-Friesian cows having genetics typical of the mid-1990s (NZ90; high milk production), and NZ Holstein-Friesian cows having genetics typical of the early 1970s (NZ70; low milk production). Cows were managed within the same pasture-based system and offered different feed allowances.

\section{MATERIALS AND METHODS}

\section{Animals and Treatments}

The study was conducted in 2003 as part of a larger trial at DairyNZ No. 2 Dairy (Hamilton, New Zealand). The trial was approved by the Ruakura Animal Ethics
Committee (Hamilton, New Zealand). The derivation of the Holstein strains used was summarized previously (Macdonald et al., 2008). Briefly, cows for the 3 strains were selected based on known pedigree information that was verified by DNA-based parentage testing performed by the Livestock Improvement Corporation (Hamilton, New Zealand). The NA90 strain ( $\mathrm{n}=74$ cows) had a predominantly NA pedigree, for which NA ancestry was defined as genetic lines developed in NA or the Netherlands for intensive confinement-style dairying with a high breeding index for profit (relative to modern NZ dairy cows). Dams selected were required to have been milk recorded and have at least 3 generations of pedigree data available. The NZ90 strain $(n=81$ cows) had a predominantly NZ pedigree, for which NZ ancestry was defined as genetic lines developed in NZ for pasture-style dairying with a high breeding index for profit (relative to modern NZ cattle). The NZ70 strain ( $\mathrm{n}=45$ cows) had a predominantly NZ pedigree with a low breeding index for profit (approximately equal to a $1970 \mathrm{NZ}$ cow). Cows in the study were in the first ( $\mathrm{n}=$ $50)$, second $(\mathrm{n}=36)$ or third $(\mathrm{n}=114)$ parity.

Cows were managed in a pasture-based dairying system in which cows calve within a defined early-spring calving season. Detailed descriptions of the trial and feeding systems were published previously (Macdonald et al., 2008). Briefly, the pasture consisted of a mixture of perennial ryegrass (Lolium perenne L.) and white clover (Trifolium repens L.), and cows grazed in a rotational-grazing manner, returning to defined grazing areas only when more than 2 leaves had grown on the majority $(>66 \%)$ of perennial ryegrass tillers. Macdonald et al. (2008) reported 3 to 4 feed allowances per strain. For the purposes of this experiment, feed allowances were grouped into "high" (6.9 to 7.2, 6.8 to 7.0 , and 5.7 to 6.2 for NA90, NZ90, and NZ70, respectively) and "low" (5.8 to 6.1, 5.6 to 6.1 , and 5.0 for NZ90, NZ90, and NZ70, respectively). Supplements, predominantly corn silage and corn grain, were added to the diet when pasture quality or amount was deemed insufficient.

Cows were milked twice daily. Milk production and milk composition (protein, fat, and lactose percentages) were determined weekly by recording milk weights and collecting milk samples at consecutive evening and morning milkings. Milk composition was determined by near-infrared spectroscopy. Milk $\mathrm{NE}_{\mathrm{L}}$ was calculated by using the following formula: $\mathrm{NE}_{\mathrm{L}}(\mathrm{Mcal})=9.29 \times \mathrm{kg}$ of fat $+5.47 \times \mathrm{kg}$ of protein $+3.95 \times \mathrm{kg}$ of lactose (NRC, 2001). Body weight and BCS (1 to 10 scale, with $1=$ thin to $10=$ obese; Roche et al., 2004) were recorded once weekly after the morning milking. Data for the first $16 \mathrm{wk}$ of lactation were analyzed and are presented. 


\section{Blood Sampling, Isolation of Plasma, and Analyses of Hormone Concentrations}

Blood was collected from a subset of study cows for each strain [NA90 $(\mathrm{n}=38)$, NZ90 $(\mathrm{n}=42)$, and NZ70 $(\mathrm{n}=30)]$ on a single morning once every $14 \mathrm{~d}$. Blood samples were collected from cows until they were at least 16 wk postpartum, and samples were grouped into 2 -wk postpartum intervals. Week 1 represented samples collected on any day from 1 to $14 \mathrm{~d}$ postpartum; wk 3 represented samples collected on any day from 15 to $28 \mathrm{~d}$ postpartum, and so forth. Blood $(10 \mathrm{~mL})$ was collected by coccygeal venipuncture into evacuated, sodium heparinized tubes (Vacutainer, Becton Dickinson, Franklin Lakes, NJ). Blood samples were held on ice before centrifugation for plasma isolation $(1,120$ $\times g$ for $\left.12 \mathrm{~min}, 4^{\circ} \mathrm{C}\right)$. Plasma samples were stored at $-20^{\circ} \mathrm{C}$. Plasma GH, IGF-I, and insulin concentrations were analyzed by RIA using methods similar to those described by Burke and Roche (2007). The intra- and interassay coefficients of variation were, respectively, 12.8 and $3.2 \%$ for GH, 17.0 and $8.8 \%$ for IGF-I, and 11.8 and $12.3 \%$ for insulin.

\section{Tissue Sampling, RNA Extraction, and mRNA Analyses}

Collection of Liver Samples. Liver tissue was collected from a subset of study cows $(\mathrm{n}=8$ for each of NA90, NZ90, and NZ70 strains, with cows offered both a high and low feed allowance represented in each strain). Second- and third-parity cows that had calved between July 31, 2003, and August 22, 2003, were used. Samples were collected at 5 times relative to parturition. The first sample was collected approximately 1 wk prepartum $(5.1 \pm 0.7 \mathrm{~d}$ prepartum). Subsequent samples were collected during postpartum wk 1 (5.1 \pm $0.3 \mathrm{~d}), 4(27.1 \pm 0.3 \mathrm{~d}), 8(55.4 \pm 0.4 \mathrm{~d})$, and $12(83.5$ $\pm 0.6 \mathrm{~d})$. A region on the right rib cage at the 11 th intercostal space (approximately $225 \mathrm{~cm}^{2}$ in size) was clipped and cleansed with chlorhexidine disinfectant and $70 \%$ ethanol. Local anesthesia $(5 \mathrm{~mL}$ of $2 \%$ lidocaine hydrochloride solution, s.c.) was then administered at the site of incision and a no. 10 surgical blade was used to penetrate the skin. Samples (approximately 200 mg) were collected with a custom-made liver biopsy needle (23 cm length, $3 \mathrm{~mm}$ i.d.; Rhone-Poulenc Rorer NZ Ltd., Auckland, New Zealand). Liver samples were placed in screw-capped microcentrifuge tubes, frozen in liquid nitrogen immediately after collection, and transported to the laboratory. Samples were stored at $-80^{\circ} \mathrm{C}$ until RNA extraction.

A blood sample was collected immediately before liver biopsy. Plasma was harvested and stored accord- ing to the procedures described above. The plasma samples were assayed for GH, IGF-I, and insulin (methods described above) and NEFA, glucose, and BHBA. Analyses for NEFA (colorimetric method), glucose (hexakinase method), and BHBA (dehydrogenase method) were performed on a Hitachi 717 analyzer (Roche, Basel, Switzerland) at $30^{\circ} \mathrm{C}$ by Alpha Scientific Ltd. (Hamilton, New Zealand).

Isolation of RNA and Preparation of $c D N A$ from Liver Tissue. Total cellular RNA was isolated from the liver by using a modified guanidinium thiocyanate method (Chomczynski and Sacchi, 1987). Tissue was homogenized with $1 \mathrm{~mL}$ of lysis solution [5 M guanidine thiocyanate, $25 \mathrm{mM}$ sodium citrate, $0.5 \%$ (wt/vol) sodium lauryl sarcosinate, $1.0 \%$ (vol/vol) 2-mercaptoethanol] and then precipitated by addition of $100 \mu \mathrm{L}$ of $2 M$ sodium acetate (pH 4) and $350 \mu \mathrm{L}$ of $96 \%$ ethanol and incubated on ice for $10 \mathrm{~min}$. Pellets were collected by centrifugation at $13,000 \times g$ for $15 \mathrm{~min}$ at $4^{\circ} \mathrm{C}$ and then resuspended in $0.5 \mathrm{~mL}$ of TRI Reagent (Molecular Research Centre Inc., Cincinnati, OH), mixed with 100 $\mu \mathrm{L}$ of chloroform by vigorous vortexing, and placed on ice for $10 \mathrm{~min}$. Samples were centrifuged at 13,000 $\times \mathrm{g}$ for $15 \mathrm{~min}$ at $4^{\circ} \mathrm{C}$, and the aqueous supernatants were transferred to new tubes, where total RNA was isolated by addition of an equal volume of isopropanol (precipitation), and were incubated at $-20^{\circ} \mathrm{C}$ for at least 20 min. Precipitated RNA was collected by centrifugation at $13,000 \times g$ for 15 min at $4^{\circ} \mathrm{C}$, and pellets were washed with $70 \%$ ethanol and resuspended in $25 \mu \mathrm{L}$ of $10 \mathrm{~m} M$ Tris, $0.5 \mathrm{mM} \mathrm{MnCl}{ }_{2}$ (pH 7.6). To remove traces of genomic DNA, RNA was treated with $2 \mathrm{U}$ of RQ1 RNase-free DNase (Promega, Madison, WI) and incubated at $37^{\circ} \mathrm{C}$ for $30 \mathrm{~min}$. The DNase treatment was stopped by incubation with $3 \mu \mathrm{L}$ of Stop Solution [25 mM ethyleneglycol-bis( $\beta$-aminoethyl ether) $N^{\prime} N$ tetracetic acid; Promega] at $65^{\circ} \mathrm{C}$ for $10 \mathrm{~min}$. The RNA content of each liver RNA sample was calculated based on absorbance at $260 \mathrm{~nm}$. The integrity of RNA was confirmed by agarose gel electrophoresis with ethidium bromide staining. The RNA samples were stored at $-80^{\circ} \mathrm{C}$. A cDNA copy of total RNA was prepared by using the SuperScript III reverse transcriptase firststrand cDNA synthesis kit (Invitrogen, Carlsbad, CA) according to the instructions of the manufacturer, with oligo $(\mathrm{dT})_{15}$ (Roche Molecular Systems, Pleasanton, $\mathrm{CA}$ ) and random hexamers used to prime the reactions. The cDNA samples were stored at $-20^{\circ} \mathrm{C}$.

Quantitative Reverse Transcription-PCR. Bovine-specific primers were designed for GHR 1A, total GHR [all variants (GHRtot)], IGF-I, and ubiquitin (Table 1). The GHR 1A, GHRtot, IGF-I, and ubiquitin primer pairs were based on previous publications (Pfaffl et al., 2003; Radcliff et al., 2003a). Appropriate PCR 
Table 1. Nucleotide sequence, direction, length of amplified product, and GenBank accession number for primers used in quantitative reverse transcription- $\mathrm{PCR}^{1}$

\begin{tabular}{|c|c|c|c|c|}
\hline Gene $^{2}$ & $\begin{array}{l}\text { Primer } \\
\text { direction }\end{array}$ & Primer sequence & $\begin{array}{l}\text { Length, } \\
\text { bp }\end{array}$ & GenBank \\
\hline GHR 1A & $\begin{array}{l}\text { Forward } \\
\text { Reverse }\end{array}$ & $\begin{array}{l}\text { CCAGCCTCTGTTTCAGGAGTGT } \\
\text { TGCCACTGCCAAGGTCAAC }\end{array}$ & 86 & U15731 \\
\hline GHRtot & $\begin{array}{l}\text { Forward } \\
\text { Reverse }\end{array}$ & $\begin{array}{l}\text { GGTATGGATCTCTGGCAGCTG } \\
\text { CTCTGACAAGGAAAGCTGGTGTG }\end{array}$ & 97 & NM176608 \\
\hline IGF-I & $\begin{array}{l}\text { Forward } \\
\text { Reverse }\end{array}$ & $\begin{array}{l}\text { TTGGTGGATGCTCTCCAGTTC } \\
\text { GCACTCATCCACGATTCCTGT }\end{array}$ & 114 & X15726 \\
\hline UBC & $\begin{array}{l}\text { Forward } \\
\text { Reverse }\end{array}$ & $\begin{array}{l}\text { ATGCAGATCTTTGTGAAGAC } \\
\text { CTTCTGGATGTTGTAGTC }\end{array}$ & 189 & $\mathrm{Z} 18245$ \\
\hline
\end{tabular}

${ }^{1}$ Primer sequences are shown $5^{\prime}$ to $3^{\prime}$.

${ }^{2} \mathrm{GHR}=$ growth hormone receptor; GHRtot $=$ total of all GHR transcripts; UBC $=$ ubiquitin.

amplification for each primer pair was confirmed by using $80 \mathrm{n} M$ each primer, $0.625 \mathrm{U}$ of HotStar Taq DNA polymerase (Qiagen, Valencia, CA), $200 \mu M$ deoxynucleotide 5'-triphosphates (Roche Molecular Systems), $1 \times$ Qiagen PCR buffer supplemented with $\mathrm{MgCl}_{2}$ to $2.5 \mathrm{mM}$, template cDNA, and sterile water in a total volume of $25 \mu \mathrm{L}$. Amplification conditions consisted of an initial denaturation of $94^{\circ} \mathrm{C}$ for $10 \mathrm{~min}$, followed by 40 cycles of $94^{\circ} \mathrm{C}$ for $15 \mathrm{~s}, 55^{\circ} \mathrm{C}$ for $15 \mathrm{~s}$, and $72^{\circ} \mathrm{C}$ for 30 s. The amplifications were performed with a PTC-100 thermocycler (MJ Research Inc., Reno, NV).

Real-time PCR reactions were undertaken in a total volume of $25 \mu \mathrm{L}$, containing $80 \mathrm{n} M$ each primer (forward and reverse), $0.625 \mathrm{U}$ of HotStar Taq DNA polymerase (Qiagen), $200 \mu M$ deoxynucleotide 5 'triphosphates (Roche Molecular Systems), 1× Qiagen PCR buffer supplemented with $\mathrm{MgCl}_{2}$ to $2.5 \mathrm{mM}, 0.5 \mu \mathrm{L}$ of Rox reference dye (Invitrogen), $0.25 \mu \mathrm{L}$ of a 200 -fold dilution of GelStar (Cambrex, East Rutherford, NJ), 0.15\% (vol/vol) Triton X-100, 35 ng of template cDNA (total RNA equivalent), and sterile water. Amplification conditions consisted of an initial denaturation step of $95^{\circ} \mathrm{C}$ for $10 \mathrm{~min}$, followed by 40 cycles of $94^{\circ} \mathrm{C}$ for $20 \mathrm{~s}, 55^{\circ} \mathrm{C}$ for $10 \mathrm{~s}, 68^{\circ} \mathrm{C}$ for $30 \mathrm{~s}$, and determination of fluorescence at $80^{\circ} \mathrm{C}$ for $15 \mathrm{~s}$. In addition, melting curve analysis was performed, which resulted in single product-specific melting temperatures above $80^{\circ} \mathrm{C}$ for each primer pair, confirming the specificity of the PCR amplification. All real-time amplifications were performed in triplicate by using an ABI Prism 7700 Sequence Detection System (Applied Biosystems, Foster City, CA).

All reaction plates contained internal controls. The controls consisted of cDNA samples known to contain high, medium, or low amounts of GHR and IGF-I mRNA and a no-template control (water substituted for cDNA) that was used to detect the amplification of false positives. Data are presented as the expression relative to the medium control sample and corrected for ubiquitin gene expression (housekeeping reference gene that was found uniformly expressed across treatments and times). The following equation was used to calculate expression relative to the control: relative expression $=\left(\text { Eff }_{\text {target }}\right)^{\Delta \mathrm{Ct} \text { (target) }} /\left(\text { Eff }_{\text {reference }}\right)^{\Delta \mathrm{Ct} \text { (reference) })}($ Pfaffl, 2001). The numerator refers to the PCR amplification efficiency $\left(\right.$ Eff $_{\text {target }}$ ) and the $\Delta \mathrm{Ct}$ for the target gene (GHR 1A, GHRtot, and IGF-I), where $\Delta \mathrm{Ct}$ (target) $=\mathrm{Ct}_{\text {control }}-\mathrm{Ct}_{\text {sample. }}$. The denominator refers to the PCR amplification efficiency for ubiquitin (Eff reference $_{\text {) }}$ ) and the $\Delta \mathrm{Ct}$ for ubiquitin, where $\Delta \mathrm{Ct}$ (reference) $=$ $\mathrm{Ct}_{\text {control }}-\mathrm{Ct}_{\text {sample }}$. The $\mathrm{Ct}$ is the cycle at which the minimum threshold was reached, whereas the efficiency is the fold-increase in a specific target for 1 amplification cycle. The efficiencies of amplification were 1.71, 1.67, 1.81, and 1.68 for GHR 1A, GHRtot, IGF-I, and ubiquitin, respectively.

\section{Statistical Analyses}

Cows within a strain were grouped into high or low feed allowances. Cows were classified as either first parity or second-third parity (2 classifications). Analyses of production and endocrine data were performed by using the mixed models procedure (PROC MIXED; SAS Institute, 2000). The statistical model included effects of strain, parity, feed allowance (i.e., feed), strain $\times$ feed, week, strain $\times$ week, parity $\times$ week, feed $\times$ week, and strain $\times$ feed $\times$ week interactions. Cow nested within strain $\times$ parity $\times$ feed was defined as the subject variable, and week was defined as the repeated variable. The data were analyzed by using the autoregressive (1) covariance structure $[\mathrm{AR}(1)]$. Data collected from cows that underwent liver biopsies were analyzed by PROC MIXED. Either compound symmetry or heterogeneous compound symmetry was used as the covariance structure. Cows were balanced for feed amount, but there were too few individual cows at each feeding amount to perform a powerful statistical analysis for feed allowance. The model included the effects of strain, week, 
and the strain $\times$ week interaction. Cow within strain was defined as the subject variable. Week relative to calving was defined as the repeated variable. Data are presented as least squares means and standard errors of the least squares means. The PDIFF procedure in PROC MIXED was used for means separation.

\section{RESULTS}

\section{Production Characteristics}

Daily milk yield and the percentages of fat, protein, and lactose in milk, daily milk net energy production, and cow BCS were all affected $(P<0.001)$ by week postpartum. Main effects and their interactions with week are described in the subsequent sections.

Milk Volume and Fat, Protein, and Lactose Percentages. There was an effect of strain $(P<$ $0.001)$, parity $(P<0.001)$, and feed allowance $(P<$ $0.001)$ on daily milk yield. The NA90 cows produced more milk than the NZ90 cows, which produced more than the NZ70 cows $(26.2 \pm 0.3,24.1 \pm 0.3$, and 20.1 $\pm 0.4 \mathrm{~kg} / \mathrm{d}$, respectively; mean \pm SEM; Figure 1A). Multiparous cows produced more milk than primiparous cows $(27.0 \pm 0.2$ vs. $19.9 \pm 0.3 \mathrm{~kg} / \mathrm{d})$. There was a strain $\times$ feed interaction $(P<0.001)$. Relative to a low feed allowance, the NA90 and NZ70 cows offered a high feed allowance had greater milk production (27.0 \pm 0.4 and $25.5 \pm 0.4 \mathrm{~kg} / \mathrm{d}$ for NA90 high allowance and NA90 low allowance; $22.1 \pm 0.4$ and $18.0 \pm 0.6$ $\mathrm{kg} / \mathrm{d}$ for NZ70 high allowance and NZ70 low allowance, respectively), whereas additional feed allowance did not increase milk production in NZ90 cows $(23.7 \pm 0.3$ and $24.4 \pm 0.4 \mathrm{~kg} / \mathrm{d}$ for NZ90 high allowance and NZ90 low allowance, respectively). The parity $\times$ week interaction was significant $(P<0.001)$, with more persistent milk production in first-parity cows.

There was an effect of strain $(P<0.001)$ and the strain $\times$ week interaction $(P<0.001)$ on the milk fat percentage (Figure 1B). The NA90 cows had a lower milk fat percentage than either of the NZ strains, particularly after 8 wk postpartum. There was a strain $\times$ feed interaction, because NZ90 cows had an increase in milk fat percentage in response to additional feed (4.81 \pm 0.04 and $4.55 \pm 0.05 \%$; high and low allowance, respectively). The NA90 and NZ70 cows did not have a greater milk fat percentage in response to additional feed allowance $(4.22 \pm 0.05$ and $4.33 \pm 0.05 \%$ for NA90 high allowance and NA90 low allowance; $4.51 \pm 0.05$ and $4.64 \pm 0.07 \%$ for NZ70 high allowance and NZ70 low allowance, respectively). Likewise, for milk protein percentage, there was an effect of strain $(P<0.001)$ and a strain $\times$ feed interaction $(P<0.001$; Figure $1 C)$. The NZ90 cows had the greatest milk protein percent- age. The NZ90 cows had an increase in milk protein percentage in response to additional feed allowance (3.61 \pm 0.03 and $3.43 \pm 0.03 \%$; high and low allowance, respectively). An increase in milk protein percentage in response to feed allowance was not observed in NA90 $(3.38 \pm 0.03$ and $3.38 \pm 0.03 \%)$ or NZ70 (3.29 \pm 0.03 and $3.29 \pm 0.04 \%$ ) cows (high and low allowance, respectively). Milk lactose percentage was greater in NZ90 cows $(4.92 \pm 0.01 \%)$ compared with NA90 (4.84 $\pm 0.01 \%)$ or NZ70 $(4.86 \pm 0.02 \%)$ cows (strain, $P<$ 0.001; Figure 1D). Milk from multiparous cows had a lower lactose percentage than milk from primiparous cows (4.83 \pm 0.01 vs. $4.92 \pm 0.02 \%$, respectively; $P<$ $0.001)$.

Net Energy in Milk and BCS. There was an effect of strain $(P<0.001)$ and parity $(P<0.001)$ on the daily Mcal of $\mathrm{NE}_{\mathrm{L}}$ in milk. The NA90 and NZ90 cows produced more milk $\mathrm{NE}_{\mathrm{L}} / \mathrm{d}$ than the NZ70 cows $(20.1 \pm 0.2,19.7 \pm 0.2$, and $15.8 \pm 0.3 \mathrm{Mcal} / \mathrm{d}$, respectively; Figure 2A), but did not differ from each other. Multiparous cows produced more milk $\mathrm{NE}_{\mathrm{L}} / \mathrm{d}$ than primiparous cows $(21.3 \pm 0.1$ vs. $15.8 \pm 0.2 \mathrm{Mcal} / \mathrm{d})$. Although the NA90 and NZ90 strains appeared to differ for time of peak lactation (earlier in NA90; Figure $2 \mathrm{~A}$ ), the strain $\times$ week interaction for milk $\mathrm{NE}_{\mathrm{L}}$ was not significant. There was a strain $\times$ feed interaction for milk $\mathrm{NE}_{\mathrm{L}}(P<0.001)$. Relative to a low feed allowance, the NA90 and NZ70 cows offered a high feed allowance had greater milk $\mathrm{NE}_{\mathrm{L}}$ production $[20.6 \pm 0.3$ and $19.7 \pm 0.3 \mathrm{Mcal} / \mathrm{d}$ for NA90 high allowance and NA90 low allowance (Figure 3A); $17.3 \pm 0.3$ and 14.4 $\pm 0.4 \mathrm{Mcal} / \mathrm{d}$ for NZ70 high allowance and NZ70 low allowance (Figure 3E)]. Additional feed allowance did not increase milk $\mathrm{NE}_{\mathrm{L}}$ production in NZ90 cows $[19.8 \pm$ 0.3 and $19.6 \pm 0.3 \mathrm{Mcal} / \mathrm{d}$ for high feed allowance and low feed allowance (Figure 3C)]. The parity $\times$ week interaction was significant for milk $\mathrm{NE}_{\mathrm{L}}(P<0.001$; more persistent milk $\mathrm{NE}_{\mathrm{L}}$ production in first-parity cows).

There was an effect of strain $(P<0.001)$ and parity $(P<0.001)$, and a tendency for a strain $\times$ feed interaction $(P=0.07)$ on BCS. The NA90 cows had lower BCS than the NZ90 or NZ70 cows $(4.0 \pm 0.1,4.4 \pm 0.1$, and $4.6 \pm 0.1$, respectively; Figure 2B). Multiparous cows had lower BCS than primiparous cows $(4.2 \pm 0.1$ vs. $4.5 \pm 0.1)$. Relative to cows offered a low feed allowance, the NZ90 and NZ70 cows offered a high feed allowance tended to have a greater BCS [4.6 \pm 0.1 and $4.2 \pm 0.1$ for NZ90 high and low allowance, respectively (Figure 3C); $4.7 \pm 0.1$ and $4.4 \pm 0.1$ for NZ70 high and low allowance, respectively (Figure $3 \mathrm{E}$ )]. Additional feed allowance did not increase BCS in NA90 cows [4.0 \pm 0.1 and $4.0 \pm 0.1$ for NA90 high allowance and NA90 low allowance (Figure 3A)]. 


\section{Plasma Hormone Concentrations}

The effect of week postpartum was significant for IGF-I $(P<0.001)$, GH $(P<0.05)$, and insulin $(P<$ $0.01)$. Interactions of week with strain, parity, and feed were not significant. Main effects and their interactions are described in the subsequent sections.

Plasma $\boldsymbol{G H}$. There was an effect of strain on plasma GH concentrations because NA90 cows had greater plasma GH than NZ90 cows, which had greater plasma GH than NZ70 cows $(1.57 \pm 0.09,1.07 \pm 0.08$, and 0.69

$\mathbf{A}$

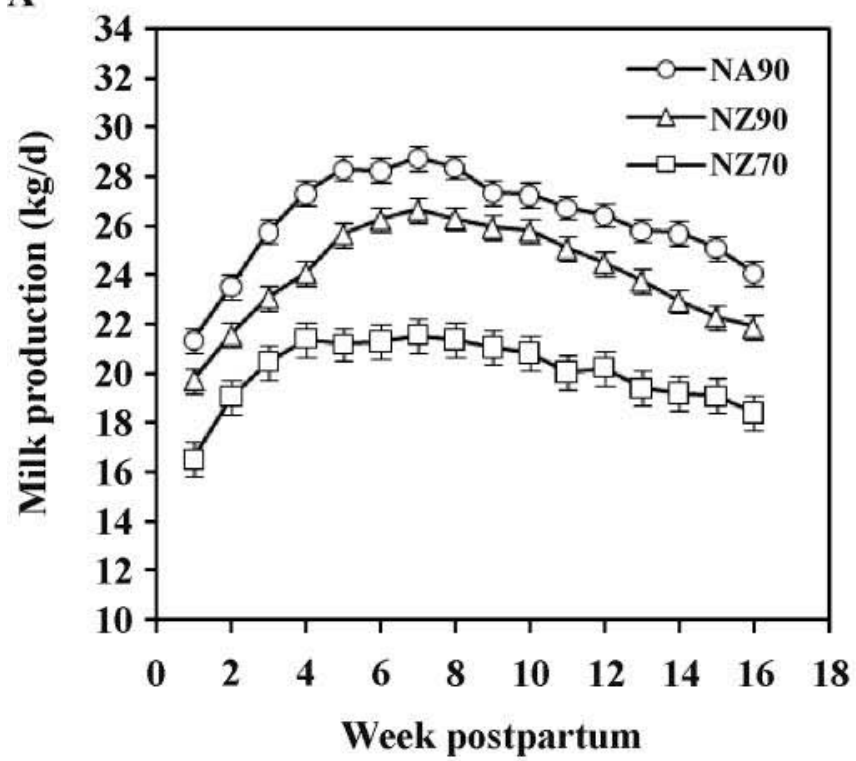

C

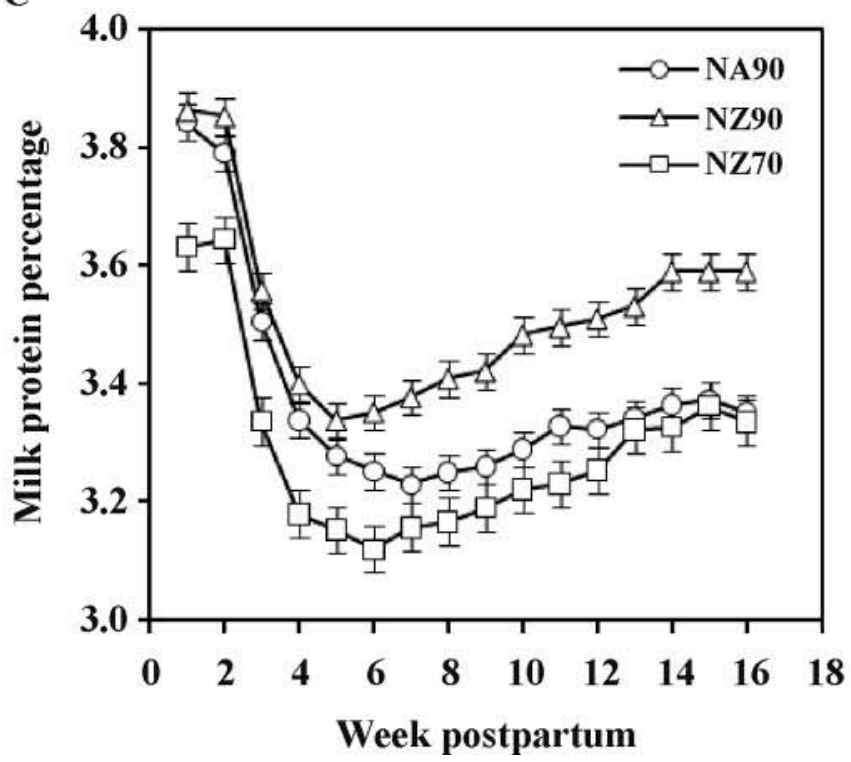

$\pm 0.09 \mathrm{ng} / \mathrm{mL}$, respectively; Figure $2 \mathrm{C}$ ). There was a tendency $(P=0.06)$ for an effect of feed allowance, with cows offered a high feed allowance tending to have lower plasma GH compared with cows offered a low feed allowance $(1.02 \pm 0.07$ and $1.20 \pm 0.07 \mathrm{ng} / \mathrm{mL}$, respectively; Figure 3B, 3D, and 3F). The strain $\times$ feed interaction was not significant for plasma GH.

Plasma IGF-I. There was an effect of strain $(P<$ $0.001)$ and parity $(P<0.001)$ on plasma IGF-I concentrations. The NA90 cows had lower plasma IGF-I compared with the NZ90 cows, which had lower plasma
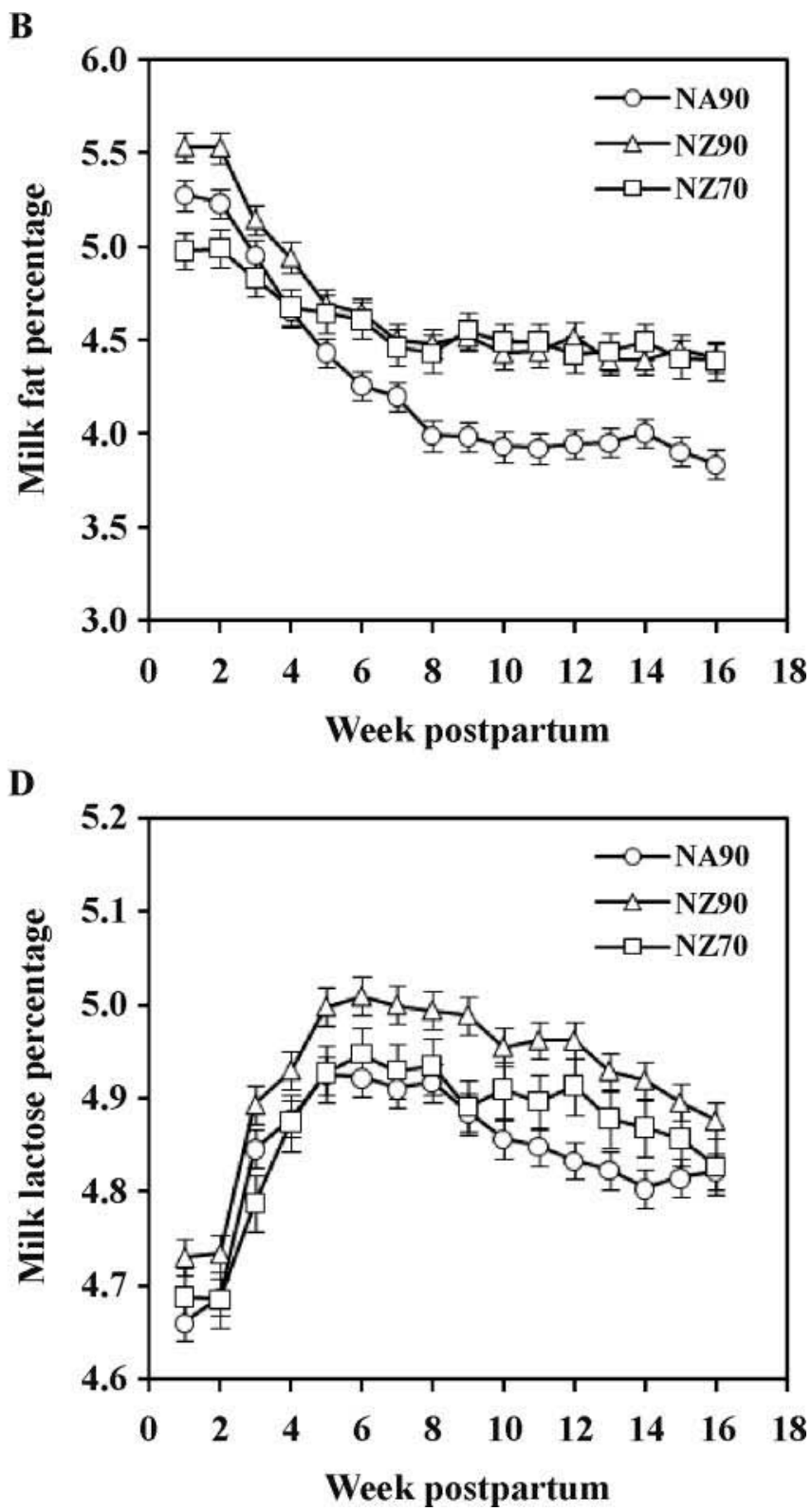

Figure 1. Least squares means and SEM for (A) daily milk production, (B) milk fat percentage, (C) milk protein percentage, and (D) milk lactose percentage during the first 16 wk postpartum in 3 divergent genetic strains of dairy cows managed in a pasture-based system [North American Holstein-high production (NA90; $\mathrm{n}=74$ ), New Zealand Holstein-Friesian-high production $($ NZ90; $\mathrm{n}=81$ ), and New Zealand Holstein-Friesian-low production $(\mathrm{NZ70} ; \mathrm{n}=45)]$. 
IGF-I compared with the NZ70 cows $(14.8 \pm 1.1,17.0$ \pm 1.0 , and $21.9 \pm 1.2 \mathrm{ng} / \mathrm{mL}$, respectively; Figure 2D). Multiparous cows had lower plasma IGF-I than primiparous cows $(11.1 \pm 0.7$ vs. $24.7 \pm 1.2 \mathrm{ng} / \mathrm{mL})$. There was a strain $\times$ feed interaction $(P<0.01)$ for plasma IGF-I. Plasma IGF-I concentrations for NA90 and NZ70 cows underwent little change in response to a high feed allowance compared with a low feed allowance $[15.9 \pm 1.5$ and $13.8 \pm 1.5 \mathrm{ng} / \mathrm{mL}$ for NA90 high allowance and NA90 low allowance (Figure 3B); 20.5 \pm 1.6 and $23.2 \pm 1.6 \mathrm{ng} / \mathrm{mL}$ for NZ70 high allowance and NZ70 low allowance (Figure 3F)]. The NZ90 cows offered a high feed allowance had greater plasma IGF-I concentrations when compared with cows offered a low feed allowance $[20.9 \pm 1.4$ and $13.2 \pm 1.4 \mathrm{ng} / \mathrm{mL}$ for NZ90 high allowance and NZ90 low allowance (Figure $3 \mathrm{D})]$.

Insulin. Plasma insulin concentrations were not affected by strain or diet. There was a tendency for an effect of parity $(P=0.07)$ because multiparous cows
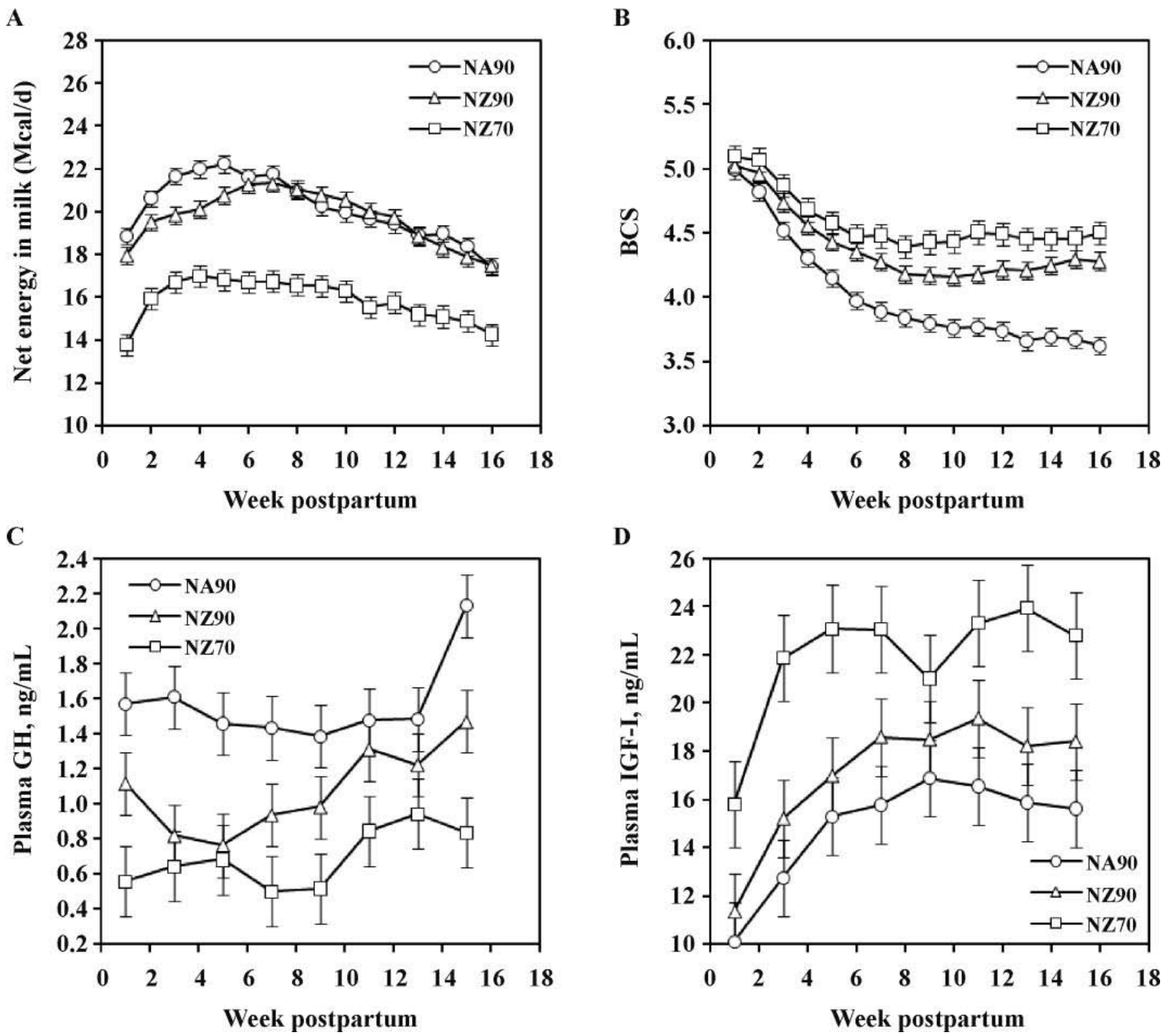

Figure 2. Least squares means and SEM for the (A) net energy in milk, (B) BCS (10-point scoring system, $1=$ thin to $10=$ obese), (C) plasma growth hormone (GH) concentration, and (D) plasma IGF-I concentration during the first 16 wk postpartum in 3 divergent genetic strains of dairy cows managed in a pasture-based system [North American Holstein-high production (NA90), New Zealand Holstein-Friesianhigh production (NZ90), and New Zealand Holstein-Friesian-low production (NZ70)]. 
A

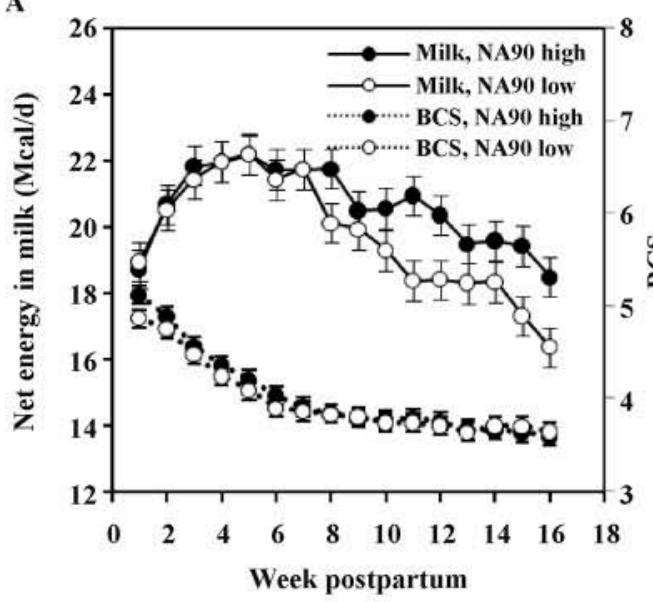

C

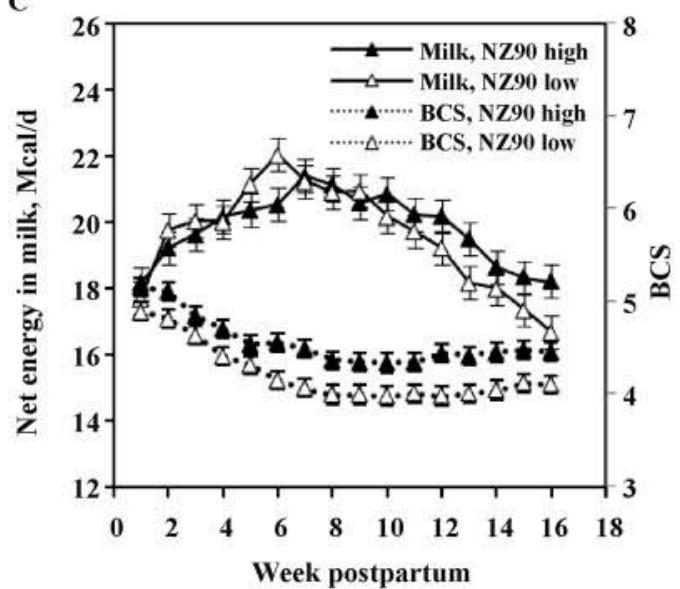

$\mathbf{E}$

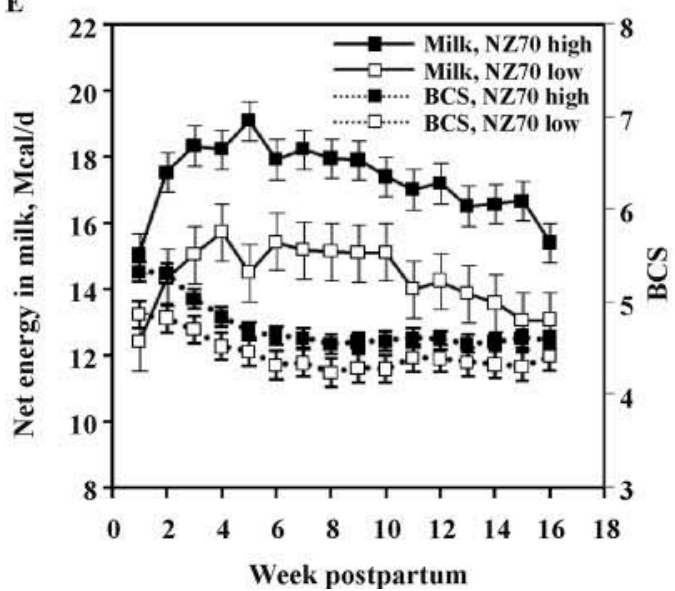

B

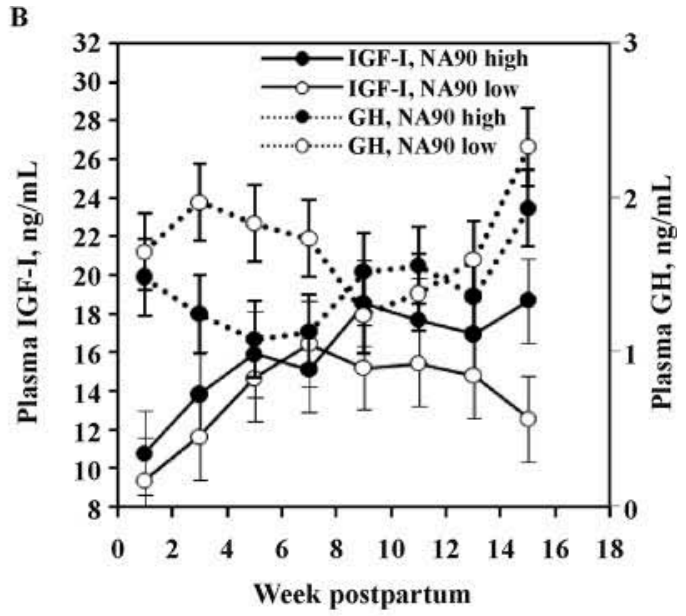

D

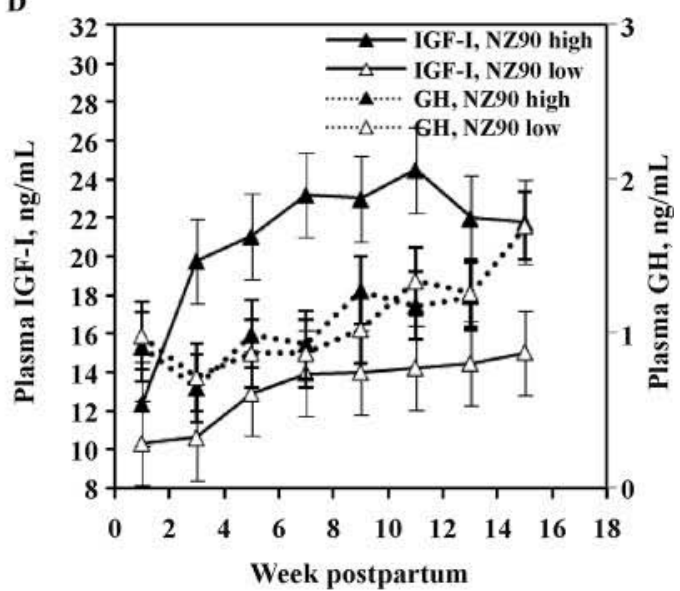

F

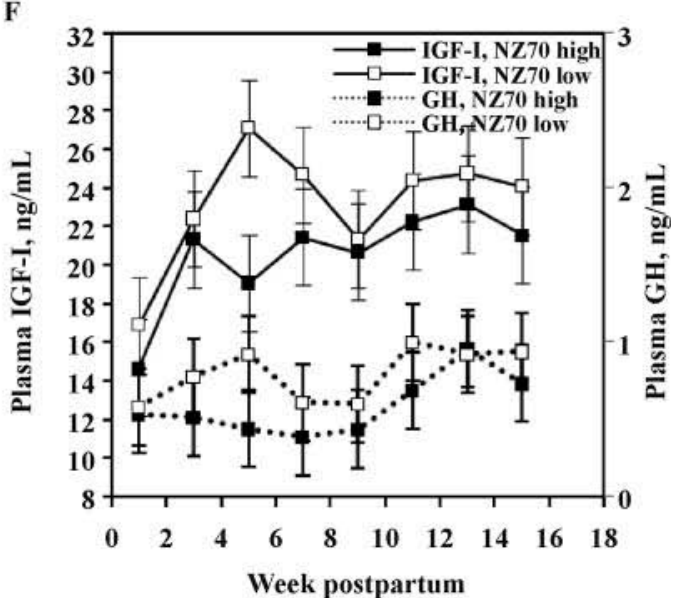

Figure 3. Least squares means and SEM for the (A, C, E) net energy in milk (Milk) and BCS (10-point scoring system, $1=$ thin to $10=$ obese), and for (B, D, F) plasma growth hormone (GH) and IGF-I concentrations during the first 16 wk postpartum in 3 different genetic strains of dairy cows [North American Holstein-high production (NA90; A, B), New Zealand Holstein-Friesian-high production (NZ90; C, D), and New Zealand Holstein-Friesian-low production (NZ70; E, F)] offered either a high (solid symbols) or low (open symbols) feed allowance. 

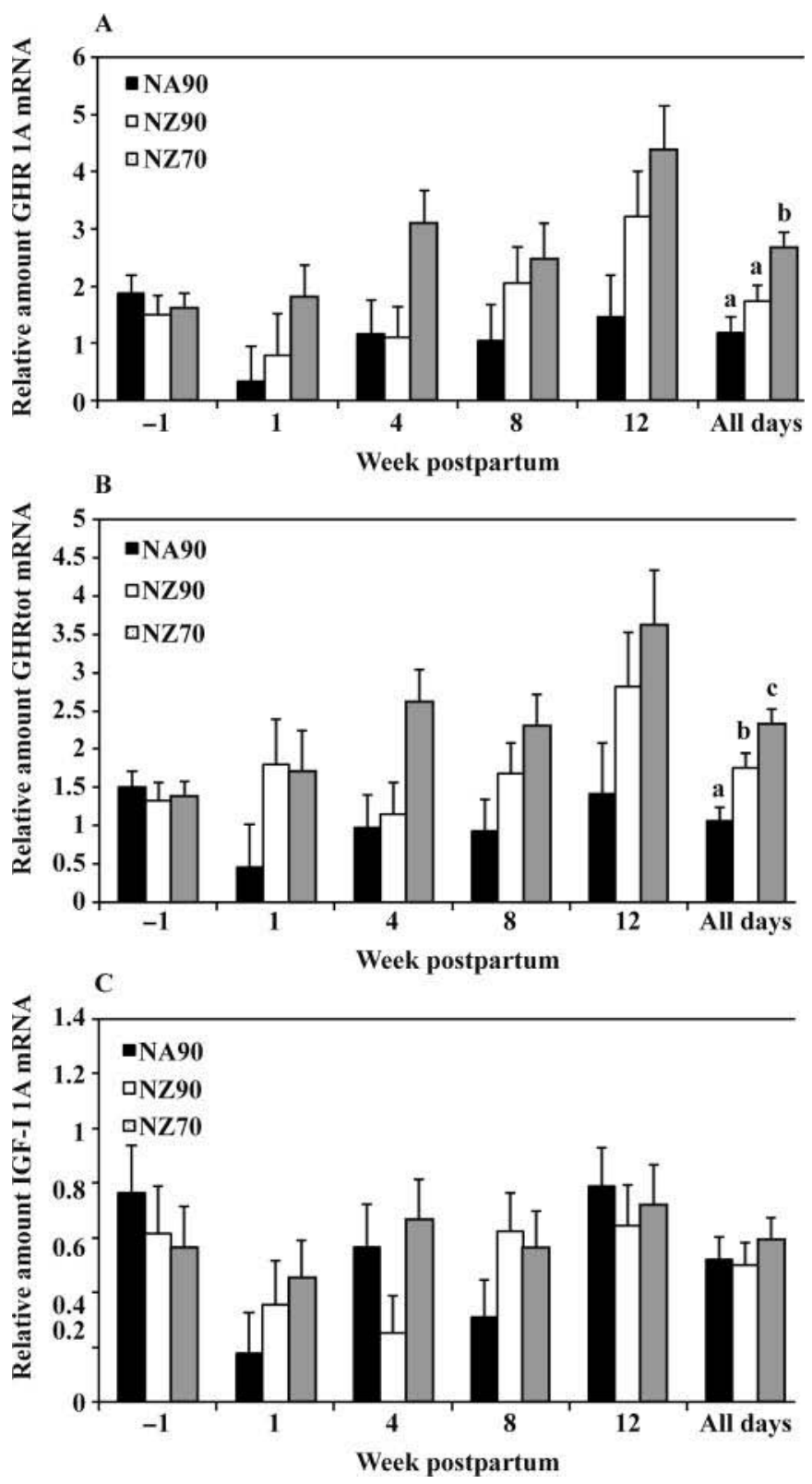

Figure 4. Least squares means and SEM for the relative amount of liver mRNA for (A) growth hormone receptor 1A (GHR 1A), (B) total growth hormone receptor (GHRtot), and (C) IGF-I in the week before calving (wk-1) or during wk 1, 4, 8, and 12 after calving. Cows were from 3 divergent genetic strains [North American Holstein-high production (NA90; $\mathrm{n}=8$ ), New Zealand Holstein-Friesian-high production (NZ90; $\mathrm{n}=8$ ), and New Zealand Holstein-Friesian-low production (NZ70; $\mathrm{n}=8$ )]. Data were adjusted for ubiquitin expression (housekeeping gene) and expressed relative to a control sample that was used in all analyses. The least squares means and SEM across all sampling days (All days) are presented $\left({ }^{\mathrm{a}-\mathrm{c}}\right.$ bars with different letters are different at $P<0.05)$.

tended to have lower plasma insulin than primiparous cows $(3.1 \pm 0.1$ vs. $3.5 \pm 0.2 \mu \mathrm{IU} / \mathrm{mL})$. Plasma insulin concentrations increased $(P<0.01)$ from $2.8 \pm 0.3$ $\mu \mathrm{IU} / \mathrm{mL}$ during wk 1 to $3.9 \pm 0.3 \mu \mathrm{IU} / \mathrm{mL}$ during wk 15.

\section{Liver mRNA and Plasma Hormone and Metabolite Concentrations for Biopsied Cows}

Liver $\boldsymbol{m R N A}$. There was an effect of strain $(P<$ $0.01)$, week $(P<0.05)$, and a tendency for a strain $\times$ week interaction $(P=0.06)$ for GHR 1A mRNA expression (Figure 4A). The liver GHRtot mRNA expression was affected by strain $(P<0.001)$, week $(P<0.10)$ and the strain $\times$ week interaction $(P<0.05$; Figure $4 \mathrm{~B})$. The observed changes in GHRtot were similar to the observed changes in GHR 1A. There was an effect of week $(P<0.02)$ on liver IGF-I mRNA expression. The amount of liver IGF-I mRNA decreased from the week before $(0.65 \pm 0.10$ relative units $)$ to the week after $(0.33$ \pm 0.08 relative units) calving. By 12 wk postpartum, liver IGF-I mRNA expression had increased to amounts similar to those prepartum (0.72 \pm 0.10 relative units). There was no effect of strain on liver IGF-I mRNA, nor was there a strain $\times$ week interaction.

Blood Hormones and Metabolites in Biopsied Cows. There was an effect of week on plasma concentrations of GH $(P<0.01)$, IGF-I $(P<0.001)$, NEFA $(P<0.001)$, BHBA $(P<0.001)$, glucose $(P<0.001)$, and insulin $(P<0.001)$ in blood samples collected from biopsied cows (Table 2). There was no effect of strain or strain $\times$ week interaction for GH, IGF-I, NEFA, or BHBA. The plasma concentrations of GH were elevated during wk 1 postpartum and subsequently decreased to wk 8. Plasma NEFA and BHBA followed the GH pattern, but elevated NEFA and BHBA appeared to persist longer than elevated GH. Postcalving plasma IGF-I concentrations were low during wk 1 and subsequently increased. There was a strain $\times$ week interaction for plasma glucose $(P<0.01)$ and a tendency for insulin $(P<0.10$; Table 2$)$. Plasma glucose and insulin concentrations decreased postpartum.

\section{DISCUSSION}

The trial presented was one of several experiments in which cows with diverse genotypes were studied in a common environment. Cows with different genetic backgrounds were identified, brought to a common location, and offered feed allowances commensurate with their predicted genetic ability to produce milk. The 3 genetic strains and the different feed allowances were selected to address 3 questions. The first question related to the performance of cows with NA genetics in a pasture-based system. This question was addressed by comparing the NA90 and NZ90 cows. The second question related to phenotypic change within cows selected within a pasture-based system. Differences between the NZ90 and NZ70 cows demonstrated this change. The third question addressed how feed allowance affected the performance of the individual strains. The experi- 
Table 2. Plasma hormone and metabolite concentrations from blood collected before biopsying the liver of dairy cows in wk -1 before calving and in wk $1,4,8$, and 12 postpartum ${ }^{1}$

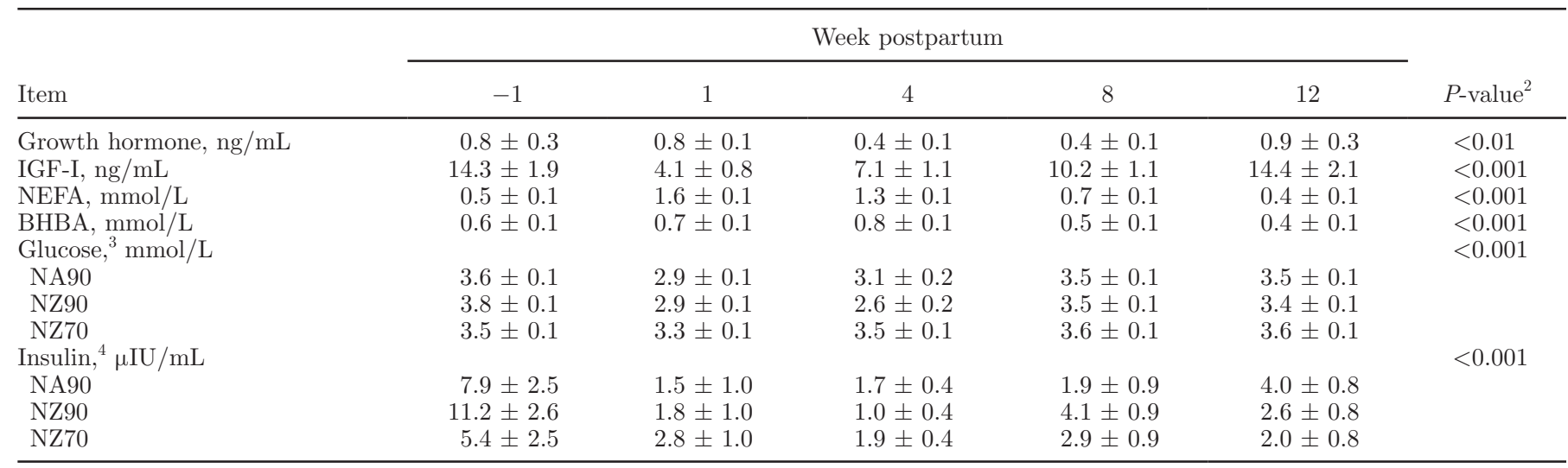

${ }^{1}$ Sampled cows were from 1 of 3 genetic strains [North American Holstein-high production (NA90), New Zealand Holstein-Friesian-high production (NZ90), and New Zealand Holstein-Friesian-low production (NZ70)].

${ }^{2} P$-value for the effect of week postpartum.

${ }^{3}$ Strain $\times$ week, $P<0.01$.

${ }^{4}$ Strain $\times$ week, $P<0.10$.

ment reported here quantified these comparisons as they related to milk production, energy balance, and the uncoupling of the somatotropic axis.

\section{Milk Production and BCS}

Milk yield during the first 16 wk postpartum was greater in NA90 cows than in NZ90 cows, which, in turn, produced more milk than NZ70 cows (Figure 1A). Both NZ strains had a greater milk fat percentage (Figure 1B), and the NZ90 strain had greater milk protein (Figure 1C) and milk lactose percentages (Figure 1D) than the other strains. The capacity of NA Holstein cows to produce greater milk yields and the capacity of NZ Holstein-Friesians to produce greater fat and protein percentages in milk have been noted in previous studies (Harris and Kolver, 2001; Roche et al., 2006; Macdonald et al., 2008) and are consistent with the internal breeding objectives of their countries of origin.

A primary objective of the current study was to examine mechanisms controlling BCS loss during early lactation. The NA90 cows lost more BCS during early lactation than the NZ90 or NZ70 cows (Figure 2B). The predominant period of BCS loss was the first $8 \mathrm{wk}$ after calving, consistent with the fitted profiles presented by Roche et al. (2006) in similar strains of lactating dairy cows. Afterward (wk 9 to 16), the NA90 cows continued to lose BCS, but at a slower rate. In comparison, the NZ strains gained BCS during this period (after 8 wk postpartum). Excessive BCS loss for cows with predominantly NA genetics was reported previously (Roche et al., 2006). The difference in BCS for NA90 cows relative to NZ70, approximately 1 BCS unit by 16 wk of lactation on the 10-point BCS scale, was equal to approximately 0.3 units on the NA 5-point BCS scale (Roche et al., 2004).

Milk production was expressed as Mcal $\mathrm{NE}_{\mathrm{L}}$ in milk, based on kilograms of protein, fat, and lactose (Figure $2 \mathrm{~A}$ ). Although total milk $\mathrm{NE}_{\mathrm{L}}$ during the first $16 \mathrm{wk}$ was nearly identical for the NA90 and NZ90 cows, a distinct difference appeared in the shape of the $\mathrm{NE}_{\mathrm{L}}$ profile for the 2 strains. The NA90 cows ascended to peak milk energy production rapidly after calving and maintained greater milk energy production than NZ90 cows from 2 to 6 wk postpartum. This period of greater milk energy production coincided with the period of greatest BCS loss in NA90 cows (Figure 2B). This phenomenon was most pronounced in multiparous cows, but was observed in 2002 when the herd was composed of first- and second-parity cows (data not shown). The differences in milk energy production were relatively minor (approximately 10\%) and short-lived (approximately $4 \mathrm{wk}$ ). Nonetheless, the difference in milk energy production could account for most of the BCS loss in NA90 cows, because the additional $\mathrm{NE}_{\mathrm{L}}$ for milk (36 Mcal) was approximately equal to the predicted megacalories provided by the BCS loss (35 Mcal; NRC, 2001). An obvious extension of this work would be to calculate energy balance or total energy requirements of the cows on this study, or both. These data were not collected because of the inherent difficulty in estimating feed energy intake in a grazing system and in estimating empty BW gain to loss for cows in early lactation. 


\section{Genetics and the Somatotropic Axis}

Excessive BCS loss in early lactation is a characteristic of NA cows under pasture management systems (Roche et al., 2006). It is a characteristic of NA cows in the traditional NA system, in which a negative energy balance during early lactation is considered necessary to support a high amount of milk production (Drackley et al., 2006). The somatotropic axis consisting of GH, the GHR, and IGF-I is believed to control nutrient partitioning in dairy cattle (Etherton and Bauman, 1998; Lucy et al., 2001; Lucy, 2008). Components of this axis were examined to determine whether GH was coordinating the changes in BCS in study cows. Growth hormone concentrations were greater in NA90 cows, particularly during the first 9 wk of lactation (Figure 2C). Growth hormone facilitates lipolysis during early lactation (Etherton and Bauman, 1998). The greater loss in BCS for NA90 cows (Figure 2B) could perhaps be explained by the greater plasma $\mathrm{GH}$ concentrations in NA90 cows (Figure 2C). It is possible that the NA90 cows had a greater capacity to synthesize milk during early lactation and that the elevated plasma GH concentrations simply reflected a greater negative energy balance in NA90 cows. In the case of either passive or direct involvement of the mammary gland, the elevated plasma GH concentrations were associated with greater BCS loss in NA90 cows.

The somatotropic axis is uncoupled in high-producing cows in early lactation; this is when the liver fails to respond to GH, producing less IGF-I (Lucy et al., 2001; Lucy, 2008). Strain differences in the relationship between blood GH and blood IGF-I concentrations in the current study indicate a genetic effect in the uncoupling of the axis. The NA90 cows had the greatest blood GH concentrations (Figure 2C), but had the lowest blood IGF-I concentrations (Figure 2D). The NZ70 cows were on the opposite end of the spectrum, having the lowest blood GH concentrations and the greatest blood IGF-I concentrations, and the NZ90 cows were intermediate. Data indicated a failure of the liver to respond to $\mathrm{GH}$ in NA90 cows, and blood IGF-I concentrations remained low despite the relatively high blood GH concentrations. Insulin-like growth factor-I is the primary systemic negative feedback hormone for GH (Le Roith et al., 2001; Etherton, 2004). Uncoupling of the somatotropic axis in NA90 cows is the most plausible reason for the low systemic IGF-I and high systemic GH concentrations, through loss of IGF-I negative feedback. The GH-IGF-I axis was uncoupled to a lesser extent or not at all in the NZ70 cows. In these cows, the liver secreted a greater concentration of IGF-I despite relatively low blood GH concentrations. The high circulating IGF-I concentrations theoretically kept blood GH concentrations low through the negative feedback loop. The NZ90 cows were intermediate between NA90 and NZ70 in blood GH and IGF-I concentrations, indicating that genetic differences not only determined whether the axis was uncoupled, but also determined the degree of uncoupling.

Circulating IGF-I is bound to several IGFBP. The IGFBP can modify the actions of IGF-I by increasing IGF-I half-life in the circulation and also by determining the amount of free IGF-I that can interact with IGF receptors (LeRoith et al., 2001; Etherton, 2004). The amount of IGFBP in the blood can change with physiological status (including nutrition and energy balance) and can potentially modify the action of IGF-I. We did not measure IGFBP in this study, but their possible role within the responses we observed is worthy of future study.

\section{Expression of Hepatic Growth Hormone Receptor mRNA}

The uncoupling of the somatotropic axis is coordinated by the expression of the GHR. The primary mRNA transcript for liver GHR is GHR 1A, the expression of which was highly correlated with liver GH binding and liver IGF-I synthesis (Radcliff et al., 2003a,b). In high-producing cows, GHR 1A mRNA expression is decreased shortly after calving, during the period in which the somatotropic axis is uncoupled. The current theory holds that the loss of GHR 1A leads to a loss in liver GH response, a decline in IGF-I synthesis, and an increase in GH through lower IGF-I negative feedback (Lucy et al., 2001; Lucy, 2008). Growth hormone receptor 1A mRNA was measured to determine whether the 3 dairy strains differed in postpartum GHR 1A expression. A limited number of cows balanced for feed amount were sampled. Cows from the 3 strains were similar for GHR $1 \mathrm{~A}$ during the week before calving (Figure 4A). Within 1 wk after calving, the expression of GHR 1A was less. Later sample dates revealed a high amount of GHR 1A expression in NZ70 cows, which was greater than the expression found in NA90 cows (Figure 4A). The GHRtot mRNA expression (a compilation of all GHR mRNA transcripts) had a profile that was somewhat similar to GHR 1A (Figure 4B).

The low expression of GHR 1A that occurred in NA90 cows explains the uncoupling that occurs within the somatotropic axis of NA90 cows. Failure to establish GHR 1A expression leads to low GHR protein expression and an uncoupled somatotropic axis. The capacity of NZ70 cows to retain GHR 1A expression suggests that their somatotropic axis was not uncoupled. These data on GHR 1A in NA90 and NZ70 cows are consistent with conclusions drawn from the plasma GH and IGF-I anal- 
yses from this study, indicating that there is a genetic influence determining whether the somatotropic axis is uncoupled, the degree to which it is uncoupled, and the duration of uncoupling. The physiology of GHR 1A for the NZ70 cows was similar to that of beef cattle; beef cattle do not undergo a decrease in GHR 1A at calving and do not appear to uncouple their somatotropic axis postpartum (Jiang et al., 2005).

Selection for milk production in NZ (NZ90 vs. NZ70) has apparently changed GHR 1A expression toward a NA phenotype, because the NZ90 cows were similar to the NA90 cows when data from all days were considered (Figure 4A). It is possible that continued selection for milk production in NZ will drive GHR 1A expression to reduced concentrations. This may be associated with greater $\mathrm{GH}$ refractoriness in liver, greater blood GH concentrations, and lower BCS in modern NZ dairy cows.

The liver IGF-I mRNA (Figure 4C) and blood IGF-I concentrations (Table 2) for biopsied cows demonstrated the expected weekly pattern, a decrease after calving that was followed by a postpartum increase, but the effects of strain were not significant. This may reflect the limited number of liver biopsied cows in this study. It is possible that the mRNA expression for GHR 1A was more consistent than that for IGF-I, and this may reflect localized differences for IGF-I expression in the liver. Although plasma IGF-I concentrations did not achieve statistical significance for strain for the biopsied cows, the rank order observed in Figure 2D (larger number of study animals) was maintained (data not shown). In general, analyses of hormones and metabolites in biopsied cows demonstrated expected changes for week postpartum, although these failed to detect strain effects. This may simply reflect too few biopsied cows in the analysis, or the fact that plasma metabolite concentrations in cows with vastly different amounts of production, and hence different capacities to clear metabolites from the blood, do not accurately reflect the rate of metabolic processes.

\section{Nutrition and the Somatotropic Axis}

Nutrition can exert control over the somatotropic axis through its effects on liver IGF-I production (Lucy, 2008). This study demonstrated a unique interaction between nutrition (i.e., feed allowance) and genetics in controlling the somatotropic axis within a pasturebased system. There was a tendency for a strain $\times$ feed interaction $(P=0.07)$ on BCS. This interaction, and, in particular, the lack of effect of feeding amount on BCS in NA cows (Figure 3A), is similar to the fitted BCS profiles presented by Roche et al. (2006) in similar strains. Kolver et al. (2005), in investigating similar strains of dairy cows, found that NA90 cows produced greater marginal milk responses to supplementary feeds than did NZ90 cows and that NA90 cows had lower BCS throughout lactation.

Plasma IGF-I concentrations are an indicator of postpartum energy balance and the extent of the uncoupling of the somatotropic axis (Lucy et al., 2001; Lucy, 2008). In high-producing dairy cows, the somatotropic axis is uncoupled shortly after calving. Recoupling of the axis requires heightened liver GHR expression and the reestablishment of liver IGF-I synthesis and secretion. The recoupling event depends on nutrition and energy balance (because better nutrition and a more positive energy balance lead to liver GHR expression and liver IGF-I synthesis and secretion; Butler et al., 2003; Radcliff et al., 2006). Compared with the low feed allowance, the high feed allowance had little effect on blood IGF-I concentrations in NA90 cows (Figure 3B), indicating a failure of the increased feed allowance to recouple the somatotropic axis. Consistent with this, additional feed failed to improve the BCS in NA90 cows (Figure 3A). The NA90 cows apparently stayed within a catabolic state (negative energy balance) during early lactation, perhaps because maintenance requirements and the capacity of the mammary gland to produce milk exceeded nutrient availability, even under generous feeding conditions on grazed pastures.

The NZ70 cows had elevated blood IGF-I concentrations relative to the other genetic strains (Figure 3). Additional feed allowance in NZ70 cows had little effect on their blood IGF-I concentrations; the somatotropic axis appeared fully functional, so blood IGF-I concentrations could not be driven higher by additional feed allowance. The NZ70 cows were similar to the NA90 cows, because in both cases, a high feed allowance failed to increase blood IGF-I and the additional feed energy was partitioned toward milk production in early lactation. In the NA90 cows, the somatotropic axis was uncoupled in early lactation, and this enabled a greater peak milk production (before $6 \mathrm{wk}$; Figure 3A) than that in NZ70 cows; the high peak milk production in NA90 cows was achieved regardless of the feed allowance, depending instead on adipose tissue mobilization. In the NZ70 cows, the somatotropic axis was not uncoupled in early lactation, and NZ70 cows responded to the high feed allowance by having greater milk production throughout the first 16 wk (i.e., before as well as after peak lactation; Figure 3E). Several implications arise from these data and from the comparison of NZ70 and NA90 cows. In particular, retaining a coupled somatotropic axis in early lactation (NZ70 cows) will thwart excessive BCS loss in early lactation and create a scenario in which the production of milk and the consumption of feed are closely linked before and after peak milk produc- 
tion. In such a scenario, milk production depends on feed consumption. This situation clearly did not exist in NA90 cows, for which additional feed allowance had little effect on milk production before 8 wk postpartum. Instead, NA90 cows used their adipose tissue reserves for the production of milk before wk 8 and apparently did not have the capacity to consume additional feed for the purpose of conserving adipose tissue or increasing milk production in early lactation. Effects of additional feed allowance in NA90 cows were observed only after peak milk production, when adipose tissue reserves were depleted (Figure 3A). Interestingly, the timing of this effect of feed allowance in NA90 cows was similar to the galactopoietic effect of recombinant bST on milk production (Bauman, 1999).

Equally intriguing was the response of NZ90 cows to the additional feed. The NZ90 cows with a low feed allowance had plasma IGF-I concentrations that were nearly equivalent to those of NA90 cows (Figure 3D). When allocated additional feed (high feed allowance) the plasma IGF-I profile of NZ90 cows shifted upward by approximately $10 \mathrm{ng} / \mathrm{mL}$. This large increase led to an endocrine IGF-I status that was nearly equivalent to that of NZ70 cows. Improved IGF-I status for the high feed allowance in NZ90 cows was associated with the partitioning of nutrients toward adipose tissue (as evidenced by greater BCS in NZ90 cows on the high feed allowance from 6 wk postpartum; Figure 3C). Physiologically, the NZ90 cows had the capacity to recouple their somatotropic axis and shift toward a more anabolic state in response to the additional feed allowance. Such a strain effect on BCS was reported by Roche et al. (2006). The shift toward an anabolic state (greater IGF-I and BCS) was accomplished without an appreciable change in blood GH concentrations (Figure $3 \mathrm{D})$, perhaps because of greater sensitivity of the liver to GH (recoupled somatotropic axis).

There were too few individual cows at each feeding amount in the biopsied group to determine the effect of feed allowance on the expression of GHR 1A mRNA and to confirm the interaction between strain and feed allowance at a gene expression level. Further research is planned to determine the effect of nutrition on the expression of key genes involved in the somatotropic axis in pasture-based cows.

\section{CONCLUSIONS}

Genetically diverse cows were studied within a pasture-based system that included a high or low feed allowance. The NA90 cows reached peak milk yield earlier during lactation and lost more BCS during early lactation when compared with NZ90 or NZ70 cows. The greater BCS loss during early lactation in NA90 cows was associated with elevated blood $\mathrm{GH}$ and low blood IGF-I concentrations. Additional feed allowance in NA90 cows failed to change blood IGF-I concentrations or BCS loss. The NZ90 cows were different in this regard, because additional feed allowance shifted IGF-I concentrations and lessened BCS loss in early lactation. The NZ90 cows had the capacity to recouple their somatotropic axis and shift toward a more anabolic state in response to the additional feed allowance. The NZ70 cows retained a coupled somatotropic axis during early lactation and increased milk production in response to additional feeding, with little change in BCS. Despite the diversity of genotypes represented in this study, changes in components of the somatotropic axis explained the relationship between milk production, BCS, and feed allowance in a NZ pasture system.

\section{ACKNOWLEDGMENTS}

The authors gratefully acknowledge the help afforded them by DairyNZ technical and farm staff, A. Sheahan, J. Lancaster, and C. Leydon-Davis. This work was funded by the Dairy InSight (Wellington, New Zealand) research fund. This research was supported in part by DairyNZ Inc. (Wellington, New Zealand) and the Missouri Agricultural Experiment Station (Columbia, MO).

\section{REFERENCES}

Bauman, D. E. 1999. Bovine somatotropin and lactation: From basic science to commercial application. Domest. Anim. Endocrinol. $17: 101-116$.

Burke, C. R., and J. R. Roche. 2007. Effects of pasture feeding during the periparturient period on postpartum anovulation in grazed dairy cows. J. Dairy Sci. 90:4304-4312.

Butler, S. T., A. L. Marr, S. H. Pelton, R. P. Radcliff, M. C. Lucy, and W. R. Butler. 2003. Insulin restores GH responsiveness during lactation-induced negative energy balance in dairy cattle: Effects on expression of IGF-I and GH receptor 1A. J. Endocrinol. 176:205-217.

Chagas, L. M., J. J. Bass, D. Blache, C. R. Burke, J. K. Kay, D. R. Lindsay, M. C. Lucy, G. B. Martin, S. Meier, F. M. Rhodes, J. R. Roche, W. W. Thatcher, and R. Webb. 2007. Invited Review: New perspectives on the roles of nutrition and metabolic priorities in the subfertility of high-producing dairy cows. J. Dairy Sci. 90:4022-4032.

Chomczynski, P., and N. Sacchi. 1987. Single-step method of RNA isolation by acid guanidinium thiocyanate-phenol-chloroform extraction. Anal. Biochem. 162:156-159.

Drackley, J. K., S. S. Donkin, and C. K. Reynolds. 2006. Major advances in fundamental dairy cattle nutrition. J. Dairy Sci. 89:1324-1336.

Etherton, T. D. 2004. Somatotropic function: The somatomedin hypothesis revisited. J. Anim. Sci. 82 (E Suppl.):E239-E244.

Etherton, T. D., and D. E. Bauman. 1998. Biology of somatotropin in growth and lactation of domestic animals. Physiol. Rev. 78:745761.

Hansen, L. B. 2000. Consequences of selection for milk yield from a geneticist's viewpoint. J. Dairy Sci. 83:1145-1150.

Harris, B. L. 2005. Breeding dairy cows for the future in New Zealand. N. Z. Vet. J. 53:384-390. 
Harris, B. L., and E. S. Kolver. 2001. Review of Holsteinization on intensive pastoral dairy farming in New Zealand. J. Dairy Sci. 84(E Suppl.):E56-E61.

Jiang, H., M. C. Lucy, B. A. Crooker, and W. E. Beal. 2005. Expression of growth hormone receptor $1 \mathrm{~A}$ mRNA is decreased in dairy cows but not in beef cows at parturition. J. Dairy Sci. 88:1370-1377.

Kolver, E. S., J. R. Roche, C. R. Burke, and P. W. Aspin. 2005. Influence of dairy cow genotype on milksolids, body condition and reproduction response to concentrate supplementation. Proc. N. Z. Soc. Anim. Prod. 65:46-52.

Le Roith, D., C. Bondy, S. Yakar, J. L. Liu, and A. Butler. 2001. The somatomedin hypothesis: 2001. Endocr. Rev. 22:53-74.

Lucy, M. C. 2007. Fertility in high-producing dairy cows: Reasons for decline and corrective strategies for sustainable improvement. Soc. Reprod. Fertil. Suppl. 64:237-254.

Lucy, M. C. 2008. Functional differences in the growth hormone and insulin-like growth factor axis in cattle and pigs: Implications for post-partum nutrition and reproduction. Reprod. Domest. Anim. 43(Suppl. 2):31-39.

Lucy, M. C., H. Jiang, and Y. Kobayashi. 2001. Changes in the somatotropin axis associated with the initiation of lactation. J. Dairy Sci. 84(E Suppl.):E113-E119.

Macdonald, K. A., G. A. Verkerk, B. S. Thorrold, J. E. Pryce, J. W. Penno, L. R. McNaughton, L. J. Burton, J. A. S. Lancaster, J. H. Williamson, and C. W. Holmes. 2008. A comparison of three strains of Holstein-Friesian grazed on pasture and managed under different feed allowances. J. Dairy Sci. 91:1693-1707.

NRC. 2001. Nutrient Requirements of Dairy Cattle. 7th rev. ed. Natl. Acad. Press, Washington, DC.

Pfaffl, M. W. 2001. A new mathematical model for relative quantification in real-time RT-PCR. Nucleic Acids Res. 29:e45.
Pfaffl, M. W., S. L. Wittmann, H. H. Meyer, and R. M. Bruckmaier. 2003. Gene expression of immunologically important factors in blood cells, milk cells, and mammary tissue of cows. J. Dairy Sci. $86: 538-545$.

Radcliff, R. P., B. L. McCormack, B. A. Crooker, and M. C. Lucy. 2003a. Growth hormone (GH) binding and expression of GH receptor $1 \mathrm{~A}$ mRNA in hepatic tissue of periparturient dairy cows. J. Dairy Sci. 86:3933-3940.

Radcliff, R. P., B. L. McCormack, B. A. Crooker, and M. C. Lucy. 2003b. Plasma hormones and expression of growth hormone receptor and insulin-like growth factor-I mRNA in hepatic tissue of periparturient dairy cows. J. Dairy Sci. 86:3920-3926.

Radcliff, R. P., B. L. McCormack, D. H. Keisler, B. A. Crooker, and M. C. Lucy. 2006. Partial feed restriction decreases growth hormone receptor $1 \mathrm{~A}$ mRNA expression in postpartum dairy cows. J. Dairy Sci. 89:611-619.

Roche, J. R., D. P. Berry, and E. S. Kolver. 2006. Holstein-Friesian strain and feed effects on milk production, body weight, and body condition score profiles in grazing dairy cows. J. Dairy Sci. 89:3532-3543.

Roche, J. R., P. G. Dillon, C. R. Stockdale, L. H. Baumgard, and M. J. VanBaale. 2004. Relationships among international body condition scoring systems. J. Dairy Sci. 87:3076-3079.

Roche, J. R., K. A. Macdonald, C. R. Burke, J. M. Lee, and D. P. Berry. 2007. Associations among body condition score, body weight, and reproductive performance in seasonal-calving dairy cattle. J. Dairy Sci. 90:376-391

SAS Institute. 2000. SAS/STAT User's Guide: Version 8 Edition. SAS Inst. Inc., Cary, NC.

Shook, G. E. 2006. Major advances in determining appropriate selection goals. J. Dairy Sci. 89:1349-1361. 